\title{
EXPECTED IMPACT OF SELECTION FOR MILK YIELD ON REPRODUCTIVE PERFORMANCE TRAITS IN HOLSTEIN FRIESIAN COWS UNDER EGYPTIAN CONDITIONS
}

\author{
Amina A. Habib, G.F. Gouda, A.R. Shemeis and Manal El-Sayed \\ Department of Animal Production, Faculty of Agriculture, Ain Shams University, P.O. Box 68 Hadayek \\ Shoubra,11241 Cairo, Egypt
}

Received: 30/9/2019

Accepted: 5/1/2020

\section{SUMMARY}

Estimation of genetic and phenotypic parameters of productive (305-day yields of milk, MY305; fat, FY305 and protein, PY305) and reproductive performance traits (days open, DO; calving interval, CI and number of inseminations per conception, NSC) were calculated on 3398 lactation records of 1054 Holstein Friesian cows, daughters of 94 bulls and 691 dams using multi-trait animal model with repeated records. Expected impact of direct selection for MY305, FY305 and PY305 on reproductive performance was calculated. Heritability estimates for productive traits varied from 0.08 to 0.26 and from 0.04 to 0.19 for reproductive traits. The productive traits were highly inter-correlated genetically (0.995 to 0.998) than the reproductive traits (0.241 to 0.786). Cows which producing abundant MY305, FY305 and PY305 tended to show less reproductive efficiency in terms of longer DO ( $r_{G}=0.942$ to 0.947), longer CI ( $r_{G}=0.587$ to 0.673) and more NSC ( $r_{G}=0.769$ to 0.829). Direct selection, after one round of selection, for MY305, FY305 and PY305 is expected to result in cows with more advantageous productive performance in terms of higher MY305 (+180.22 to $323.27 \mathrm{~kg})$, FY305 $(+13.79$ to $24.95 \mathrm{~kg})$ and PY305 (+12.41 to $22.48 \mathrm{~kg})$. This enhancement in productive performance is expected to be associated with deterioration in reproductive performance in terms of longer days open $(+16.27$ to 29.48 days), longer calving interval ( +15.26 to 25.22 days) and higher number of inseminations per conception $(+.08$ to 0.16 services). It could be concluded that the undesirable relationship between productive and reproductive performance traits in Holstein Frisian cows must be taken into consideration when planning breeding programs in dairy cattle (e.g. improving productive traits by genetic selection and reproductive traits by enhancement management or by using restricted selection indices).

Keywords: Holstein-Frisian cows, productive and reproductive performance, genetic parameters, direct selection, correlated response

\section{INTRODUCTION}

For most countries, milk production, involving yields of protein and fat, has been the main objective for selection in dairy cattle (Miglior et al., 2005). From economic point of view, optimal profitability of the dairy producer can be achieved by obtaining the productive performance, in terms of high yields of milk, protein and fat, at high level while maintaining the reproductive performance, in terms of days open, calving interval and number of inseminations per conception, at acceptable level.

Continuous selection for abundant milk production has been widely related with unfavorable effects on health and fertility of cows (Zink et al., 2012; Carthy et al., 2016 and Frioni et al., 2017).

The impact of longer calving interval are manifested by lower annual yields of milk, protein and fat; lower calf-crop; more number of inseminations per conception and higher costs through longer dry periods with increase in number of veterinary treatments ( Zambrano and Echeverri, 2014; Radwan et al., 2015 and Ben Zaabza et al., 2016).

The aim of the present work was to estimate the impact of direct selection for 305-day milk yield, protein yield and fat yield on reproductive performance traits of Holstein Frisian cows based on records collected from a commercial herd raised under Egyptian conditions using the equations described by Falconer and Mackay (1996).

\section{MATERIALS AND METHODS}

\section{Source of data:}

Data of the present study were collected from Alexandria-Copenhagen private Dairy Farm (76 km from Alexandria governorate). A total number of 3398 lactation records of productive and reproductive performance traits for 1054 Holstein Friesian cows, daughters of 94 bulls and 691 dams, were used in this study. Data covered the period from 1997 to 2011.

\section{Herd management:}

All animals were kept and reared under natural environmental condition supplied with spray cooling system during hot climate to reduce heat stress effect. Holstein cows were fed on commercial ration providing 19.7 crude protein with $2567 \mathrm{kcal} / \mathrm{kg}$ containing $16.5 \%$ wheat bran, $52.0 \%$ yellow corn, $29.5 \%$ soybean meal, $1 \%$ limestone, $0.7 \%$ di-calcium phosphate and $0.3 \%$ antitoxin according to cow's body weight, milk yield and stage of lactation with $a d$-lib access to fresh water. At $375 \mathrm{~kg}$ body weight, heifers are to artificially inseminated. After birth, cows are machine milked, three times a day. The 
newborn calves were suckled artificially up to weaning at 3 months of age.

\section{Studied traits:}

The traits describing productive performance were 305-day yields of milk, MY305, fat, FY305, and protein, PY305. While those describing the reproductive performance were number of days open, $\mathrm{DO}$, calving interval, $\mathrm{CI}$, and number of inseminations per conception, NSC.

\section{Statistical analysis:}

Genetic and phenotypic parameters were estimated using a multi-traits animal model with repeated records by applying the VCE-6 software program package (Kovač et al., 2002) according to the following repeatability model:

$$
\underset{\text { Where: }}{\boldsymbol{y}}=\boldsymbol{X} \boldsymbol{b}+\boldsymbol{Z} \boldsymbol{a}+\boldsymbol{w} \boldsymbol{p}+\boldsymbol{e},
$$

$\mathbf{y}=$ the vector of observations of the studied traits,

B = the vector of fixed effects (overall mean, parity, 2-5 levels, and year-month of calving, 154 levels),

a $=$ the vector of random additive genetic direct effects,

$\mathbf{P}=$ the vector of permanent environmental effects, with each level pertaining to a common effect to all observations of each animal,

$\mathbf{X}, \mathbf{Z}=$ known incidence matrices relating and observations to the respective fixed, random W and permanent environmental effects with $\mathrm{Z}$ augmented with columns of zeros for animals with or without records, and

e $\quad=$ the vector of random residual effects.

\section{Estimation of direct and correlated responses:}

Direct response for productive performance of a given trait (DR) was calculated as:

$$
\mathrm{DR}=\mathrm{I} * \mathrm{~h}^{2} * \sigma_{P},
$$

While, the correlated response in reproductive performance of a trait Y (CRY), with direct selection applied on a trait $\mathrm{X}$, was calculated according to the following equation, as described by Falconer and Mackay (1996):

$$
C R_{Y}=I * h_{X} * h_{Y} * r_{G} * \sigma_{P(Y)}
$$

Where:

$$
\begin{array}{ll}
I= & \text { intensity of selection on } \mathrm{X}, \\
h \quad= & \text { square root of the heritability, with } \\
& \text { subscript } \mathrm{X} \text { or } \mathrm{Y}, \text { according to trait, } \\
r_{G}= & \text { genetic correlation between trait } \mathrm{X} \text { and } \\
& \text { trait } \mathrm{Y}, \text { and } \\
\sigma_{\mathrm{P}(Y) \quad} \quad & \mathrm{Y} .
\end{array}
$$

\section{RESULTS AND DISCUSSION}

\section{Levels of performance:}

Overall means of productive (MY305, FY305 and PY305) and reproductive performance traits (DO, CI and NSC) across all lactations and their phenotypic and genetic coefficients of variability are presented in Table 1. The means of MY305 $(8369.72 \mathrm{~kg}$, Table 1; 8805 kg, Rushdi et al., 2014; 8550, Samoul, 2015; $8315 \mathrm{~kg}$, Salem and Hammoud, 2016b) were much lower than the estimate of $10369 \mathrm{~kg}$ obtained by Radwan and ABO Elfadl (2016) and much higher than the estimate of $6384.95 \mathrm{~kg}$ obtained by FaidAllah (2015). The average of FY305 obtained in present study (266.06 kg, Table 1) was slightly higher than the estimates of 227 and $246.73 \mathrm{~kg}$ reported under Iranian conditions (Behzadi et al., 2013 and Salimi et al., 2017, respectively). However,

\begin{tabular}{|c|c|c|c|c|}
\hline \multirow[t]{2}{*}{ Trait } & \multirow[t]{2}{*}{ Mean } & \multicolumn{2}{|c|}{ Coefficient of variation } & \multirow[t]{2}{*}{$\mathbf{h}^{2} \pm \mathrm{SE}$} \\
\hline & & Genetic & phenotypic & \\
\hline \multicolumn{5}{|l|}{ Productive performance: } \\
\hline 305-day milk yield, MY305, kg & 8369.72 & 7.72 & 26.91 & $0.08 \pm 0.02$ \\
\hline 305-day fat yield, FY305, kg & 266.06 & 18.35 & 38.42 & $0.23 \pm 0.02$ \\
\hline 305-day protein yield, PY305, kg & 219.14 & 19.96 & 39.45 & $0.26 \pm 0.03$ \\
\hline \multicolumn{5}{|l|}{ Reproductive performance: } \\
\hline Number of days open, DO, day & 166.50 & 37.18 & 84.13 & $0.19 \pm 0.02$ \\
\hline Calving interval, CI, day & 427.72 & 19.55 & 62.48 & $0.09 \pm 0.02$ \\
\hline Number of inseminations per conception, NSC & 3.00 & 12.66 & 65.30 & $0.04 \pm 0.01$ \\
\hline
\end{tabular}
Frioni et al. (2017) recorded much lower estimate (187.3 kg) under Uruguay condition. The overall mean of PY305 in present study $(219.14 \mathrm{~kg})$ was comparable with the mean of $233.5 \mathrm{~kg}$ obtained by Salimi et al. (2017) and much higher than the estimate of $182.8 \mathrm{~kg}$ recorded by Frioni et al. (2017).

Table 1. Overall means, residual genetic and phenotypic coefficients of variation, heritabilities and their standard errors $\left(h^{2} \pm S E\right)$ for productive and reproductive performance traits considered in the present study

For reproductive performance traits, the overall mean of DO was 166.5 days (Table 1). This estimate was within the range of 113.1 to 219.15 days reported in several Egyptian studies (Radwan and ABO Elfadl, 2016; Salem and Hammoud, 2016b). Calving interval in the present study was calculated 
to be 427.72 days, which is comparable to the estimate of 430 days obtained by Abou-Bakr et al. (2006) and lower than the estimates of 452 and 484 days given by Safaa (2006) and Ibrahim et al. (2009), respectively. The overall mean of NSC (3.0, Table 1) was comparable to the estimate of 3.5 services stated by Samoul (2015). However, this estimate was much higher than the estimate of 1.9 obtained by Salem and Hammoud (2016a). The variations in estimates for productive and reproductive traits between present study and previous results may be due to the differences in herd type, number of lactations and environmental conditions (e.g. feeding, temperature, veterinary care, etc.).

\section{Variability:}

Residual phenotypic and genetic coefficients of variability for considered traits are given in Table 1 .
It seems that reproductive performance traits are more variable phenotypically than the productive traits (CVP $=62.48$ to $84.13 \%$ vs. 26.91 to $39.45 \%$ ) which revealed the effect of environmental conditions on these traits. Milk yield was the lowest variable trait genetically $(7.72 \%)$ and phenotypically (26.91\%) among the studied traits. The low estimate for the coefficient of variation in milk yield compared to fat and protein yield indicate a high homogeneous population in this trait as a result to continuous culling of cows with productive and reproductive problems by progressing in parities (Frioni et al., 2017). The stability of MY305 across years of study compared to FY305 and PY305 (Figure 1) support this finding.
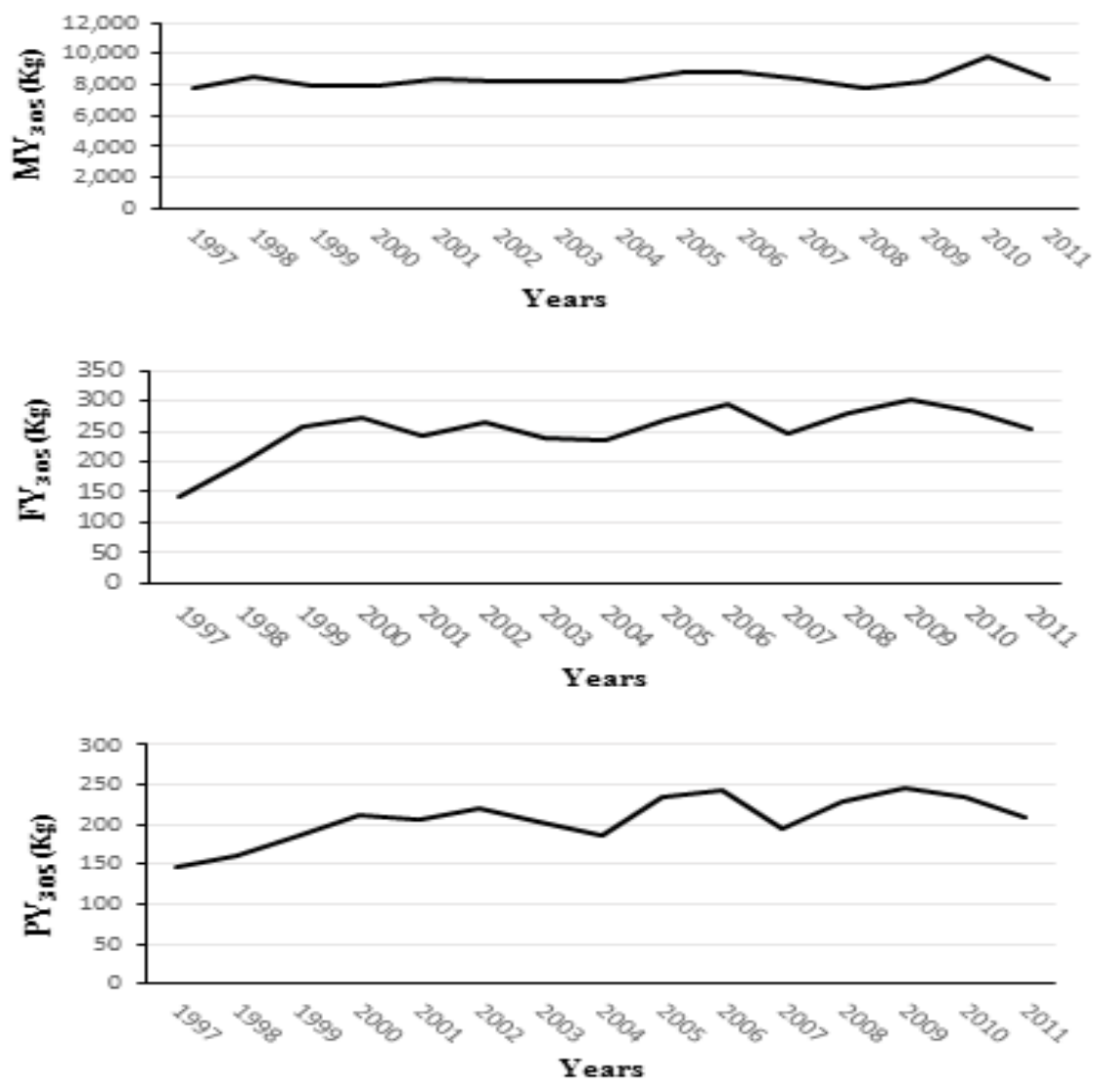

Figure 1. Change in milk production traits over calving year

\section{Heritabilities:}

Heritability estimates $\left(\mathrm{h}^{2}\right)$ for productive and reproductive traits are showed in Table 1 . The $\mathrm{h}^{2}$ estimate obtained in present study for MY305 using the multi-trait repeated animal model was found to be very low (0.08) as compared to the estimates stated in literatures. It has no counterpart in the literature and out the range of the estimates calculated either through the single animal model $(0.15-0.35$ : Sahin et al., 2012; Salem and Hammoud, 2016a and Ayalew et al., 2017) or bivariate animal model (0.16
- 0.26: Toghiani, 2012; Rushdi et al., 2014 and Ayalew et al., 2017), multi-traits animal model (0.15, Ayalew et al., 2017; 0.18, Faid-allah, 2015) and multi-traits animal model with repeated records (0.23, Frioni et al., 2017). The lower $\mathrm{h}^{2}$ estimate of MY305 in present study may be due to the differences in days in milk, days open, amount of residual variances and other sources of environmental variances from one lactation to other (Behzadi et al., 2013). 
The present $h^{2}$ estimate for fat yield (0.23) was comparable to those obtained using a similar model (0.21, Frioni et al., 2017) and bivariate animal model (0.21, Zink et al., 2012). However, these estimates are much higher than the estimates of 0.11 and 0.16 obtained using the single trait animal model (Stanojević et al., 2013; Albarrán-Portillo and Pollott, 2013, respectively).

Heritability estimate of protein yield was found to be moderate $(0.26$, Table 1$)$. This estimate was slightly higher than the estimate of 0.21 reported by Frioni et al. (2017) using similar model.

The $\mathrm{h}^{2}$ estimates of $0.19,0.18$ and 0.15 obtained for number of days open in present study and by Salem \& Hammoud (2016a) and Radwan \& ABO Elfadl (2016), respectively, are above the range of 0.03 to 0.15 given in literature (e.g. Ben Zaabza et al., 2016; Radwan and ABO Elfadl, 2016 and Ayalew et al., 2017).

Heritability estimate of calving interval (0.09, Table 1; 0.09, Zambrano and Echeverri, 2014; 0.11, Ayalew et al., 2017) was slightly higher than the estimates ranged from 0.002 to 0.07 reported in previous works (e.g. Toghiani, 2012; El-Bayoumi,
2015; Almeida et al., 2017) and much lower than the estimate of 0.28 given by Goshu et al. (2014).

The NSC in present study was estimated to be $\% 4$ heritable. Comparable estimates have been noticed in the literature (0.03 to 0.07, M'hamdi et al., 2010; Zambrano and Echeverri, 2014 and Ben Zaabza et al., 2016). However, Radwan et al. (2015) reported much higher estimate $(0.21)$ for the same trait.

The low $h^{2}$-estimates for reproductive traits revealed that improvement of performances for these traits could be achieved by improving the nongenetic factors (feeding, health and reproductive management), which vary from herd to herd, therefore enhancement of these traits through selection of superior individuals would be very slow.

In general, it is noteworthy that statistical analysis method, animal genetics, parity number, milk record number, and environmental effects may be the most important factors affecting the estimates of heritability estimates from one study to another.

\section{Genetic and phenotypic associations:}

Correlations among productive and reproductive traits are presented in Table 2 .

Table 2. Genetic (above diagonal) and phenotypic (below diagonal) correlations among productive and reproductive performance traits

\begin{tabular}{lllllll}
\hline \multicolumn{1}{c}{ Trait } & MY305 & FY305 & PY305 & DO & CI & NSC \\
\hline $\begin{array}{l}\text { Productive performance traits } \\
\text { 305-day Milk yield, MY305 }\end{array}$ & $\ldots \ldots$ & 0.995 & 0.995 & 0.942 & 0.673 & 0.769 \\
305-Fat yield, FY305 & 0.425 & $\ldots \ldots$ & 0.998 & 0.947 & 0.587 & 0.829 \\
305-Protein yield, PY305 & 0.448 & 0.886 & $\ldots \ldots$ & 0.947 & 0.617 & 0.810 \\
Reproductive performance traits & & & & & & \\
$\quad$ Days open, DO & 0.045 & 0.389 & 0.407 & $\ldots \ldots$ & 0.481 & 0.786 \\
$\quad$ Calving interval, CI & 0.272 & 0.264 & 0.250 & 0.378 & $\ldots \ldots$ & 0.241 \\
$\quad$ Number of inseminations per conception, NSC & 0.047 & 0.180 & 0.161 & 0.147 & 0.025 & $\ldots \ldots$ \\
\hline
\end{tabular}

\section{Associations among productive traits:}

It appeared that 305-day milk yield, fat yield and protein yield were strongly inter-correlated genetically (0.995 to 0.998$)$ and phenotypically (0.425 to 0.886$)$. This is in agreement with previous studies (0.69 to 0.91, Amini et al., 2011; Zavadilová and Zink, 2013; Frioni et al., 2017). Due to the high genetic correlation among productive traits, genetic selection for all traits can be achieved through selection for any of them.

\section{Associations among reproductive traits:}

Days open shows a fairly high genetic relationship with calving interval $\left(\mathrm{r}_{\mathrm{G}}=0.481\right)$. This estimate was much lower than the estimates ranged 0.85 to 0.99 reported by Ghiasi et al. (2011), Guo et al. (2014), Zambrano and Echeverri (2014), Radwan et al. (2015), El-Bayoumi (2015), Ben Zaabza et al. (2016) and Ayalew et al. (2017). However, Toghiani (2012) reported low genetic correlation $\left(\mathrm{r}_{\mathrm{G}}=0.11\right)$ between the same two traits.

High genetic relationship $\left(\mathrm{r}_{\mathrm{G}}=0.786\right)$ was found in the present study between days open and number of inseminations per conception. Similar genetic trend $\left(\mathrm{r}_{\mathrm{G}}=0.72\right.$ to 0.99$)$ has been showed in literature between the two traits (Ghiasi et al., 2011; Yamazaki et al., 2014; Zambrano and Echeverri, 2014).

Moderate relationship $\left(\mathrm{r}_{\mathrm{G}}=0.241\right)$ was recorded between CI and NSC in present study. This estimate was much lower than the estimates of 0.49 and 0.42 obtained by Guo et al. (2014) and Radwan et al. (2015), respectively.

\section{Associations between productive and reproductive traits:}

Undesirable relationship between 305-day milk yield and reproductive performance traits was noticed. This is represented in number of days open $\left(\mathrm{r}_{\mathrm{G}}=0.942\right.$, Table 2; 0.99, Salem and Hammoud, 2016a; 0.69, Frioni et al., 2017; 0.65, Zavadilová and Zink, 2013), calving interval $\left(\mathrm{r}_{\mathrm{G}}=0.673\right.$, Table 3; 0.63, Albarrán-Portillo and Pollott, 2013; 0.59, Toghiani, 2012) and number of inseminations per conception $\left(\mathrm{r}_{\mathrm{G}}=0.769\right.$, Table $2 ; 0.99$, Salem and Hammoud, 2016b).

From the genetic point of view, DO, CI and NSC are strongly correlated positively with FY305 (0.587 to 0.947 ) and PY305 (0.617 to 0.947). Generally, the 
high undesirable positive genetic correlation between productive and reproductive traits of Holstein Frisian cows, indicate that any genetic improvement in productive performance would adversely affect the reproductive performance of cows included in present study.

\section{Expected direct and correlated responses to selection:}

Expected genetic responses to direct selection for productive traits on reproductive performance are given in Table 3. At each round of selection, with intensity equal 1.0, individual direct selection for yields of milk, protein and fat is expected to develop Holstein Frisian cows with better milk production performance in terms of higher milk yield $(+180.22$ to $323.27 \mathrm{~kg})$, fat yield $(+13.79$ to $24.95 \mathrm{~kg})$ and protein yield $(+12.41$ to $22.48 \mathrm{~kg})$. However, direct selection for productive traits is expected to deteriorate the reproductive performance in terms of longer number of days open ( +16.27 to 29.48 days), longer calving interval ( +15.26 to 25.22 days) and higher number of inseminations per conception ( +0.08 to 0.16 service).

Based on the results obtained in present study, it is notable that, the correlated response in MY305 when direct selection for each of FY305 and PY305 is applied, would be higher than the direct response for MY305 itself (304.05 and $323.27 \mathrm{~kg}$, respectively vs $180.22 \mathrm{~kg}$ ). This is due to the higher heritability estimates for yields of fat and protein (0.23 and 0.26, respectively) than that of milk yield $(0.08)$ and the perfect genetic correlation among the three traits (0.995 to 0.998$)$.

Table 3. Expected direct and correlated responses to selection for productive and reproductive traits

\begin{tabular}{lllll}
\hline Response to selection & unit & \multicolumn{2}{l}{ Selection criterion } \\
\cline { 2 - 5 } & & MY305 & FY305 & PY305 \\
\hline Direct response: & $\mathrm{Kg}$ & $\mathbf{1 8 0 . 2 2}$ & $\ldots$ & $\ldots$ \\
MY305 & $\mathrm{Kg}$ & $\ldots \ldots$ & $\mathbf{2 3 . 5 1}$ & $\ldots$. \\
FY305 & $\mathrm{Kg}$ & $\ldots \ldots$ & $\ldots$. & $\mathbf{2 2 . 4 8}$ \\
PY305 & & & & \\
Correlated response in: & $\mathrm{Kg}$ & $\ldots$. & 304.05 & 323.27 \\
MY305 & $\mathrm{Kg}$ & 13.79 & $\ldots$. & 24.95 \\
FY305 & $\mathrm{Kg}$ & 12.41 & 21.09 & $\ldots$. \\
PY305 & Day & 16.27 & 27.73 & 29.48 \\
DO & Day & 15.26 & 22.57 & 25.22 \\
CI & Service & 0.08 & 0.16 & 0.16 \\
NSC & & & \\
\hline
\end{tabular}

As compared to selection for milk yield, the size of deterioration in DO, CI and NSC (9.77, 3.57 and $2.67 \%$, respectively) are expected to be higher when selection for yields of protein $(17.70,5.89$ and $5.33 \%$, respectively) and fat $(16.65,5.27$ and $5.33 \%$, respectively) is applied (Fig. 2).

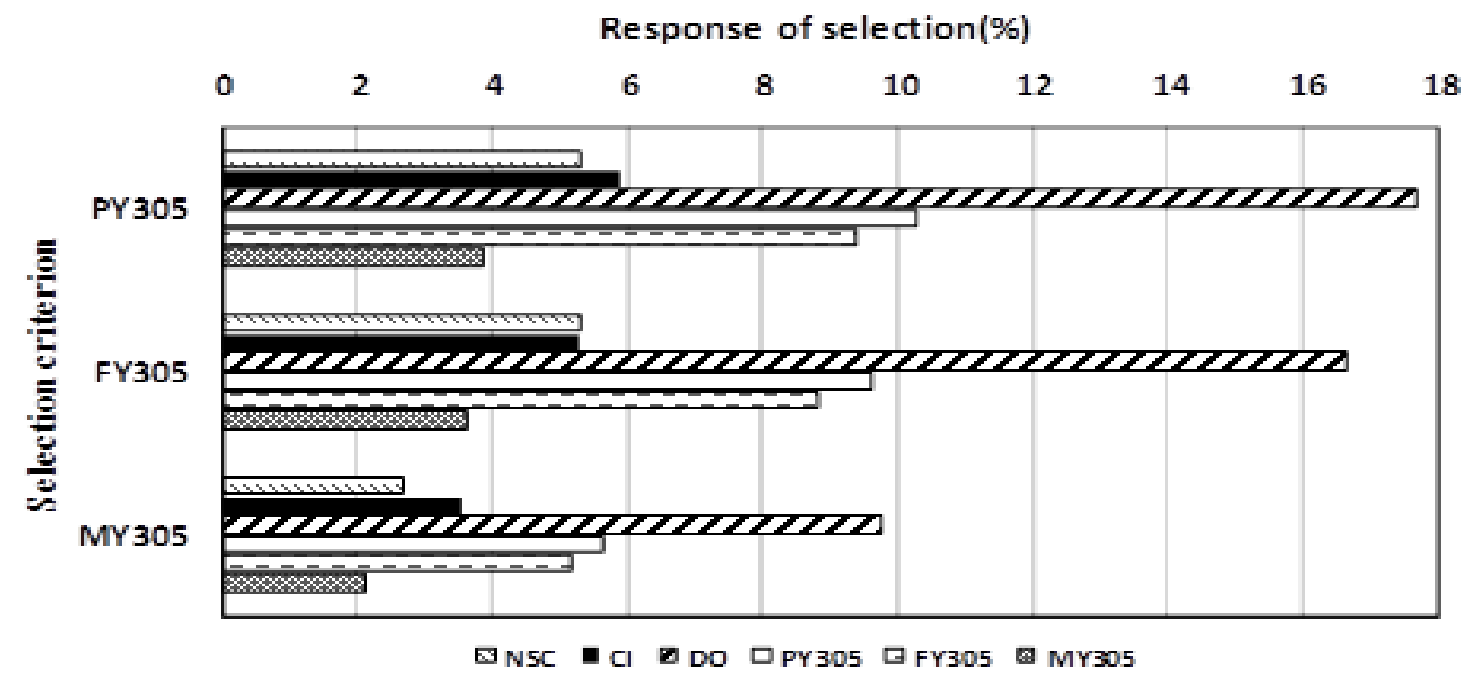

Figure 2. Expected response to selection for productive performance traits expressed as a percentage of the initial means 


\section{CONCLUSION}

It could be concluded that the genetic undesirable relationship between productive and reproductive performance traits in Holstein Frisian cows must be taken into consideration when planning breeding programs in dairy cattle.

\section{REFERENCES}

Abou-Bakr, S., H.O.A. Alhammad, R.R. Sadek and A. A. Nigm, 2006. Productive and reproductive characteristics of Holstein cows raised under intensive farming system in Egypt. Egyptian Journal of Animal Production, 43(2): 91-98.

Albarrán-Portillo, B. and G.E. Pollott, 2013. The relationship between fertility and lactation characteristics in Holstein cows on United Kingdom commercial dairy farms. Journal of dairy Science, 96(1): 635-646.

Almeida, T.P., E.L. Kern, D.D.S. J. Daltro, Braccini Neto, C. McManus, A. Thaler Neto and J.A. Cobuci, 2017. Genetic associations between reproductive and linear-type traits of Holstein cows in Brazil. Revista Brasileira de Zootecnia, 46(2): 91-98.

Amini, A., A.A. Aslmeninejad and M. Tahmuraspor, 2011. Estimation of genetic parameters for production traits of Holstein cattle in Khorasan Razavi province. Iranian Journal of Animal Science research, 3(2): 171-178.

Ayalew, W., M. Aliy, and E. Negussie, 2017. Estimation of genetic parameters of the productive and reproductive traits in Ethiopian Holstein using multi-trait models. AsianAustralasian Journal of Animal Science, 30(11):1550-1556.

Behzadi, M.B., A. Amini, A.A. Aslaminejad, and M. Tahmoorespour, 2013. Estimation of genetic parameters for production traits of Iranian Holstein dairy cattle. Livestock Research Rural Development, 25(9), uploaded from http://www.lrrd.org/lrrd25/9/bahr25156.htm.

Ben Zaabza, H., A. Ben Gara, H. Hammami, B. Jemmali, M.A. Ferchichi, and B. Rekik, 2016. Genetic parameters of reproductive traits in Tunisian Holsteins. Archives Animal Breeding, 59(2): 209-213.

Carthy, T.R., D.P. Ryan, A.M. Fitzgerald, R.D. Evans, and D.P. Berry, 2016. Genetic relationships between detailed reproductive traits and performance traits in Holstein-Friesian dairy cattle. Journal of Dairy Science, 99(2): 12861297.

El-Bayoumi, K.M., M.S. El-Tarabany, T.M. AbdelHamid, and O.M. Mikaeil, 2015. Heritability, genetic correlation and breeding value for some productive and reproductive traits in Holstein cows. Research Opinions in Animal and Veterinary Sciences, 5(2): 65-70.
Falconer, D.S. and T.F.C. Mackay, 1996. Introduction to quantitate genetic .4th Edition, Longman.

Faid-Allah, E. 2015. Genetic and non-genetic analysis for milk production and reproductive traits in Holstein cattle in Egypt. Indonesian Journal of Animal and Veterinary Sciences, 20(1):10-17.

Frioni, N., G. Rovere, I. Aguilar, and J.I. Urioste, 2017. Genetic parameters and correlations between days open and production traits across lactations in pasture based dairy production systems. Livestock Science, 204: 104-109.

Ghiasi, H., A. Pakdel, A. Nejati-Javaremi, H. Mehrabani-Yeganeh, M. Honarvar, O. GonzálezRecio, M.J. Carabaño, and R. Alenda, 2011. Genetic variance components for female fertility in Iranian Holstein cows. Livestock Science, 139(3): 277-280.

Goshu, G., S. Harpal, K. Johan Petersson and L. Lundeheim, 2014. Heritability and correlation among first lactation traits in Holstein Friesian cows at Holeta Bull Dam Station, Ethiopia. International Journal of Livestock Production, 5(3): 47-53.

Guo, G., X. Guo, Y. Wang, X. Zhang, S. Zhang, X. Li, L. Liu, W. Shi, T. Usman, X. Wang, and L. $\mathrm{Du}, 2014$. Estimation of genetic parameters of fertility traits in Chinese Holstein cattle. Canadian Journal of Animal Science, 94(2): 281-285.

Ibrahim, M.A.M., H.E. Rushdi, S.A.M. Abdel-Salam and S. Abou-Bakr, 2009. Genetic and phenotypic trends of calving interval and age at first calving in a commercial Holstein herd. Egyptian Journal of Animal Production, 46(2):103-112.

Kovač, M., E. Groeneveld and L.A. Garcia Cortes, 2002. VCE-5 User's a package for the estimation of dispersion parameters. 7th World Congr. Genet. Appl. Livest. Prod., Montpellier, France. Commun. no. 28-06, 19-23 Aug.

M'hamdi, N., R. Aloulou, S.K. Brar, M. Bouallegue and B.M. Hamouda, 2010. Phenotypic and genetic parameters of reproductive traits in Tunisian Holstein cows. Biotechnology in Animal Husbandry, 26(5-6): 297-307.

Miglior, F., B.L. Muir, and B.J. Van Doormaal, 2005. Selection Indices in Holstein Cattle of Various Countries. Journal of Dairy Science, 88(3): 12551263.

Radwan, H.A. and E.A. ABO Elfadl, 2016. Test day milk yield as a selection criterion to improve milk yield based on measures of somatic cells in Holstein cow's milk. Asian Journal of Animal and Veterinary Advances, 11(9): 516-523.

Radwan, H.A., E.A. Abo Elfadl and A.M. Fardos, 2015. Estimates of population parameters for some economic traits in Holstein Friesian cows by using statistical program. Global Veterinaria, 14(1): 129-135.

Rushdi, H.E., M.A.M. Ibrahim, N.Q. Shaddad, and A.A. Nigm, 2014. Estimation of genetic 
parameters for milk production traits in a herd of Holstein Friesian cattle in Egypt. Mansoura Journal of Animal and Poultry Production, 5(5): 267-278.

Safaa, S.S.I. 2006. Genetic analyses for some productive and reproductive traits in dairy cattle. Ph. D. Thesis, Faculty of Agriculture at Moshtohor, Banha University, Egypt.

Sahin, A., Z. Ulutas, A.Y. Adkinson, and R.W. Adkinson, 2012. Genetic and environmental parameters and trends for milk production of Holstein cattle in Turkey. Italian Journal of Animal Science, 11(3): 242-248.

Salem, M.M.I. and M.H. Hammoud, 2016a. Genetic parameters of first lactation traits of Holstein cows in Egypt. Egyptian Journal of Animal Production, 53(2): 75-80.

Salem, M.M.I. and M. H Hammoud, 2016b. Estimates of heritability, repeatability and breeding value of some performance traits of Holstein cows in Egypt using repeatability animal model. Journal of Animal Production, 53(3):147152.

Salimi, M.H., N.G. Hossein-Zadeh, A.A. Shadparvar and A.R. Eghbal, 2017. Genetic evaluation of dystocia and its relationship with productive and reproductive traits in Holstein cows. Revista Colombiana de Ciencias Pecuarias, 30(2):126137.

Samoul, A. 2015. Productive and reproductive performance of Holstein cows under different managerial conditions. Ph.D. Thesis, Faculty of Agriculture, Cairo University, Egypt.
Stanojević, D., R. Đedović, V. Bogdanović, R. Beskorovajni, P. Perišić, M. Popovac, and N. Popović, 2013. Heritability and repeatability estimation of milk yield traits of black and white cows. In 10th International Symposium (p. 1397).

Toghiani, S. 2012. Genetic relationships between production traits and reproductive performance in Holstein dairy cows. Archiv Tierzucht, 55(5): 458-468.

Yamazaki, T., K. Hagiya, H. Takeda, S. Yamaguchi, T. Osawa, and Y. Nagamine, 2014. Genetic correlations among female fertility, 305-day milk yield and persistency during the first three lactations of Japanese Holstein cows. Livestock Science, 168: 26-31.

Zambrano, J.C. and J. Echeverri, 2014. Genetic and environmental variance and covariance parameters for some reproductive traits of Holstein and Jersey cattle in Antioquia (Colombia). Revista Brasileira de Zootecnia, 43(3): 132-139.

Zavadilová, L. and V. Zink, 2013. Genetic relationship of functional longevity with female fertility and milk production traits in Czech Holsteins. Czech Journal of Animal Science, 58(12): 554-565.

Zink, V., J. Lassen and M. Štipkova, 2012. Genetic parameters for female fertility and milk production traits in first-parity Czech Holstein cows. Czech Journal of Animal Science, 57(3): 108-114.

\title{
الإسـتجابة المتوقعـة للانتخـاب لمحصـول اللبن على صفات الأداء التناسـلي لأبقـار اللهولثـتين فريزيـان تحث الظروف

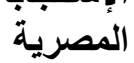

\author{
أمينة علاء الدين حبيب، جوده فتحي، أحمد راغب شميس ومنال السيد \\ قسم الإتتاج الحيوانس، كلية الزراعة، جامعة عين شعس، شبرا الخبية 1 أب 1 1 القاهرة، مصر
}

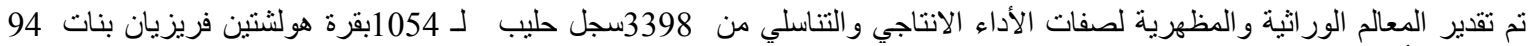

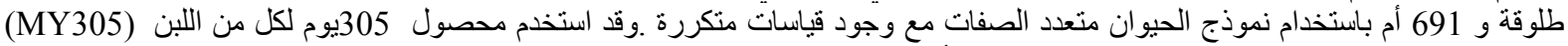

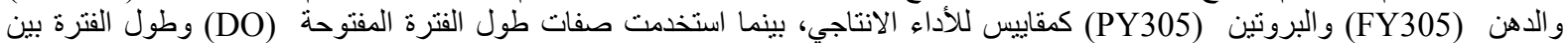

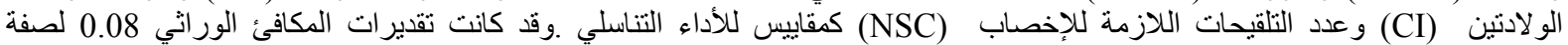

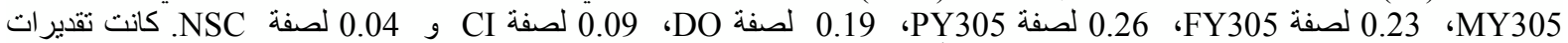

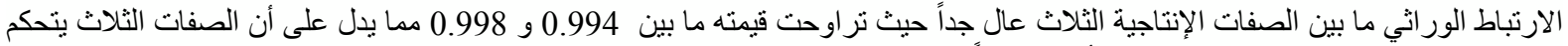

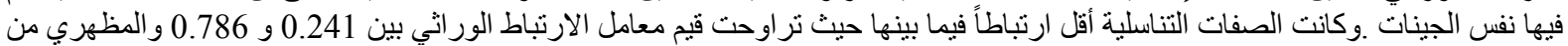



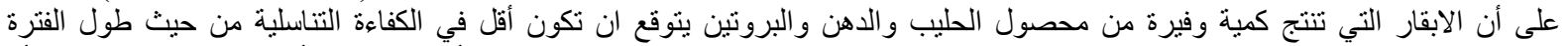

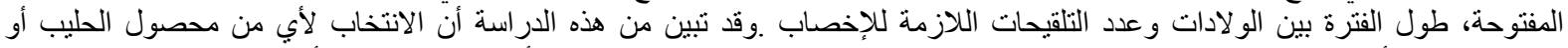

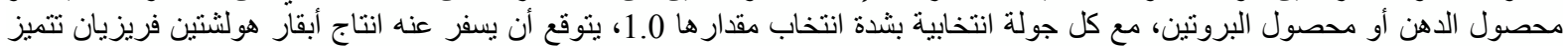

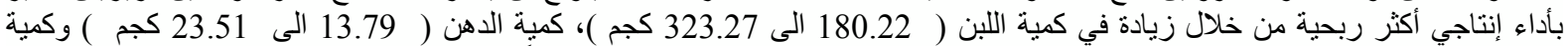

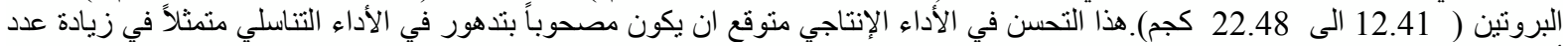



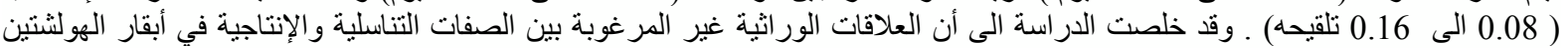



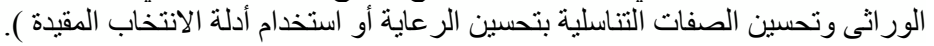

